\title{
Design and Visual Arts for Digital Literature
}

\author{
Cristina Portugal \\ CAPES Foundation, Ministry of Education of Brazil, \\ Av General Felicissimo Cardoso \\ 835, b2 701. Barra da Tijuca. \\ Rio de Janeiro, RJ. CEP 22631-360, Brazil \\ crisportugal@gmail.com
}

\begin{abstract}
This paper has as its starting point a research project entitled "Design and the contemporary digital technologies in learning process" approved, in 2014, by the scientific notice MCTI/CNPQ/Universal 14/2014 and from a research project entitled "Bilingual digital literature (LIBRAS and Portuguese)" that intends to the development of scientific, technological and innovation researches which involves new languages, projective elements and new possibilities for presentation of information by using different elements available in contemporary technologies. Among them, we can highlight the interaction, the navigation, the hypertextual levels, the connectivity, the mobility and the responsive design issues as well as informational, cognitive and projective questions that are established in different and new areas. Thus, the project will present a theoretical research combined with the conceptual basis for the development of digital interactive literature that helps the educational process. In addition, it is planned to provide a continuation of the digital book, which served as this project basis, looking forward to provide the production of an e-book collection for tablets, or similar, with multiple language narrative in hypermedia environments whose theme is the city of Rio de Janeiro.
\end{abstract}

Arts. Design. Technology. Inclusion. Visual Cultureon.

\section{INTRODUCTION}

Today our society is experiencing a relentless pursuit of time and knowledge. This reality is closely linked to the children and young people that see and act in the virtual and in the real world like they are the same and is also related to how they use the gadgets naturally. This point of view lead us to discuss that the teaching-learning field is turning into something new, beyond the border of school and the communication between teachers and students.

This study will look at the narrative as a conductor between children and their ability of learning and how the development of technology can assist in this process, combining form and content in hypermedia environments mediated by Design and Education. It will address to how the convergence and ubiquity of communication are contributing to it technologically, culturally and socially, being increasingly present in the lives of children who have access to technological resources.

The study presented in this paper was born from a research project called "Design and contemporary digital technologies applied in the development of an interactive digital book for deaf and listening children", which was contemplated in 2014 by Call Announcement: MCTI/CNPQ/Universal 14/2014 the name of Professor Cristina Portugal. This research allowed perceiving the lack of studies determining guidelines for a joint work between Design and the different areas that may contribute for building hypermedia languages to learning. The mentioned project aims to make available a series of interactive digital books for deaf and listening children and its theme is the preservation of the Cultural Heritage of the city of Rio de Janeiro.

The relevance of this investigation is on its social function, by looking for ways of reducing the barriers between deaf and listening children regarding communication. To make available guidelines leading to the creation of bilingual digital interactive tools (Brazilian language sign - LIBRAS - and Portuguese) that may be embedded in other projects for children is just the beginning to make groups of developers to think about it becoming able to reach the greater number of deaf and listening users.

This is an exploratory research of qualitative nature. It was also necessary to deepen the 
investigation about the target public. The study object is the bilingual interactive digital story, for deaf and hearing children, which is being used as the case study and will have the stages of planning and execution described and, later, analysed.

For Portugal (2013a \& 2013b), the knowledge society - as the current society may be called imposes new ways of thinking, which are changing our social behaviour. To fulfil those social demands, people must be educated and prepared for that. With the support of technology, the school can magnify its reach with the students. This study proposes to present the potential of the partnership between Design, Education and Technology and its research object is the process of creating an interactive story, aiming to reach deaf children, but not only, helping to acquire competences of LIBRAS and Portuguese languages.

A discussion about the digital narrative considering its new visual possibilities and user experience will be presented. In the words of Jenkins (2009), the digital narrative allows a new aesthetic that emerged as an answer to the convergence of media - an aesthetic that has new demands for the consumers and depends on the active participation of knowledge communities (Jenkins 2009, p.49).

\section{IMPORTANCE OF THE NARRATIVE}

The construction and development of digital narratives for Carvalho (2008) is constituted by a process of text production, that assumes the contemporary character of the audiovisual and technological resources able to modernise 'the tell stories' and that can become an efficient pedagogical tool motivating the student, while aggregating to the teaching practice the trend of insertion of reality that is so demanded from teaching practices. Oliveira (2009) adds that the child that has contact with literary works from an early age will have a much greater comprehension about itself and about the other, having the opportunity of developing its creative potential and widening its horizons about culture and knowledge. This way, its vision will be better regarding the world and the reality around it.

The digital narrative of this study prioritises the use of images for presenting the story. It is based on the precepts of Portugal et al. (2015) for building the children's digital interactive narrative, which must take into consideration, besides the story text, the images and interactive technological resources.

Therefore, it is a wide field for the research and creation of projects in the field of Design in partnership with other areas. The narrative with image and written text complement each other and allow the reader to oscillate between one and another in order to understand the story. In the children's illustrated book the images; the written text and the design elements have an integrated relationship, where the meaning of the whole is greater than the sum of the constituents' parts. Images tell what words cannot tell and vice-versa, because isolated elements are not able to tell the whole story.

Besides, the e-book may be read in several ways, depending upon its updates, both by the author as well as by the possibility of the public interfering in the histories, collaboratively. In the same way, new chapters may be added to the original story, giving continuity to its narrative. Not mentioning the new resources that appear every day, allowing new ways of interacting and navigating through the narrative.

In an observation made by the team of authors of this paper with children students from the National Deaf Education Institute ("Instituto de Educação de Surdos" - INES - Rio de Janeiro, Brazil), it was perceived the importance of producing stories for deaf children when the team was faced with the difficulty of the deaf child to locate itself both temporally as well as socially. In many cases, the deaf child becomes a member apart from its family, because it does not share the same oral form of communication. This becomes an impediment for the sociocultural values being transmitted from the parents to sons in their small daily actions to be assimilated by the child. This factor limits its interaction with the environment where it lives and may trigger a passive and insecure behaviour in its attitudes.

The deaf child properly stimulated, interacting with the world and with the people around it, constructively and participatory has a tendency of developing as naturally as any other child.

For Vygotsky (1998), the first form of communication of the child is gestural, imaginative and based in a context. Child's play helps the development and child learning because the child creates the relationships with the world around it and begins to create associations between objects, their characteristics and the meaning of words. The key for the symbolic role of child's play is in the representative gestures that the child is able to execute. Maturing, it starts to understand that objects may not only indicate the things that they represent but they may, also, replace them.

Thus, it is coherent to think that activities were imagination is stimulated, and the entertainment taken into consideration, has great chances of being elected by the child, and that the interactions between the content and the hypermedia support 
during the course of the activity are tools that make possible the learning.

This point of view corroborates with the importance of developing pleasurable activities, in which children feel stimulated and instigated to take part in. The bilingual child's digital interactive narrative (LIBRAS and written Portuguese) demands an study about themes that may collaborate for the temporal and social questions previously raised, types of graphic resources, such as illustrations and characters, the presence of two languages, such as oral Portuguese in the presence of the storyteller, the interpreter of LIBRAS and the written Portuguese, the hypermedia support to which it will be designed and, finally and as important as the previous questions, which interactive resources will take part in the narrative so that the child fells to be an agent of the knowledge building.

\section{RESEARCH METHODOLOGY}

Based on methodology from previous studies of Portugal et al. (2015) some stages were defined for developing the digital narrative. Despite the presentation in stages, the research process will be ruled by actions concomitantly executed. Figure 1 gives a summary of the methodological process of the research.

\section{METHODOLOGICAL PROCESS}

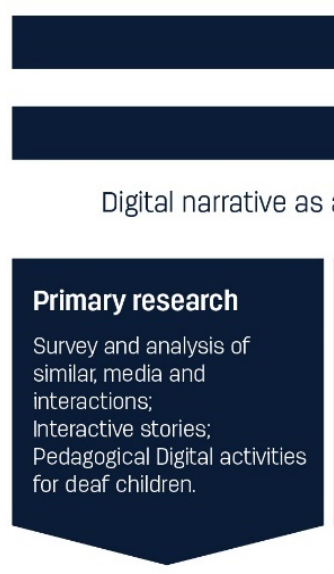

Object category

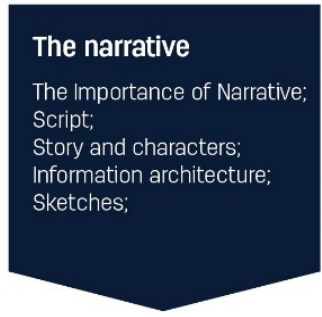

Story

\section{${ }^{\text {st }}$ STAGE: Introduction}

\section{$2^{\text {nd }}$ STAGE: Theoretical Research}

\section{$3^{\text {rd }}$ STAGE: Concept Development}

STORYBOARD

Crew: Designers, illustrator, motion graphics and translator

(Scenes e scenes illustration, scenarios e characters)

$\begin{gathered}\text { Crew: Designers, illustrator, motion graphics, translator and web developer } \\ \text { (Software development, motion graphics, interactive resources, } \\ \text { usability and accessibility - prototype) }\end{gathered}$
$\begin{gathered}\text { Crew: Designers + Deaf Children } \\ \text { (Analysis of prototype with deaf children) }\end{gathered}$
$\begin{gathered}\text { EVALUATION + ANALYSIS } \\ \text { Crew: UX Designers }\end{gathered}$
4 $^{\text {th }}$ STAGE: Guidelines for the interactive digital book
METHOD
Crew: Designers

DEVELOPMENT, VALIDATION AND ANALYSIS

FINAL CONSIDERATIONS 
Figure 1: Methodological process. Source: Files from authors.

This research is intended to generate material conditions for professionals of Design, arts and related areas for developing and producing digital literature from the new digital languages, widening the space of diffusion and cultural exchanges in and between artistic languages, in the following knowledge areas: visual arts, audiovisual, music for digital literature.

Because of that, it is expected to make available an unprecedented work of processes and criteria for the creation of interactive literature. Besides, this project aims to make available a set of hypermedia teaching materials in the format of interactive digital books having as their theme the city of Rio de Janeiro - in the sphere of a perspective of creating awareness for the valuation of the cultural heritage, activated by children, for the plenitude of the formation of their citizenship. In other words, it aims to make available interactive stories about important points that are part of the history of the city of Rio de Janeiro in digital format, aiming to innovate the teaching-learning process of deaf and listening children, based on the abilities and competences determined by the Laws of Guidelines and Bases of Children and Elementary School Education (Law Number 9,394/96).

\section{THE STORY}

The story under development is a fiction aiming to reach a public between 7 and 12 years old, however it can be consumed by people of any age, since stories may reach diverse publics.

The main theme of the story is the concern in keeping the natural balance of the ecosystem and, consequently, the awareness for preserving the nature in a city of the region of Rio de Janeiro called Grumari, a preserved reserve area of the Atlantic Forest. This story contributes with the fact that the city of Rio de Janeiro became, on 1 July 2012, the first city in the world receiving the title of World Heritage from UNESCO as an Urban Cultural Landscape. The application, made by the Institute of National Historical and Artistic Heritage (Iphan), was approved during the 36th Session of the World Heritage Committee in San Petersburg, Russia (Vianna 2012).

The choice for presenting this theme as an interactive digital narrative was since children born in the digital era have familiarity with this new reality, this evolution being part of their life. For them, it is as natural to constantly adapt to the new relations that the technologies offer as to their selfgrowing and maturing. This dynamic is part of their day-by-day and a part of it. Children applications and games are full of interactions and updates, stimulating the exchange between the content offered and the child's behaviour, making one interdependent of the other.

Another relevant factor is the easiness of navigation and the search by intuitive reactions from the users. There is no longer a need for an instruction manual, since there is a route for a time when those devices work as an extension of everybody's activities and communication. Besides, it is the user that chooses how and with which frequency it wants to receive the information and defines how to navigate to reach its objective. During this route, it is still possible to change its mind and quickly change the theme of interest/search. The individual's reasoning now has tools to execute the multilinearity in navigation.

Having the previous ideas as a concept, at the start of structuring the visual of the narrative, the same sketches were made, considering the main elements of the story, namely: Characters, Setting/Place, Time, Problem, Events (Sweetland 2017).

\section{Characters: Who is in the story?}

The story has four main characters. First of all their characteristics, personality and identity are defined by means of sketches using paper and pencil in order for, finally, adopting a party for each one and developing them. Three categories were taken into consideration: characteristics, personality and identity. Characteristics are external physical attributes, observable and superficial. Personality regards the social body, they are the qualities and defects that other people associate with it based on the way that they interpret its physical characteristics, speeches and behaviours. Finally, identity corresponds to the image that it has of itself, the qualities and defects associated to its personality, the labels used to describe who it is (and who it is not), the references considered as relevant for judging its value as a person.

To exemplify this, some sketches that were shaping the visual narrative are presented.

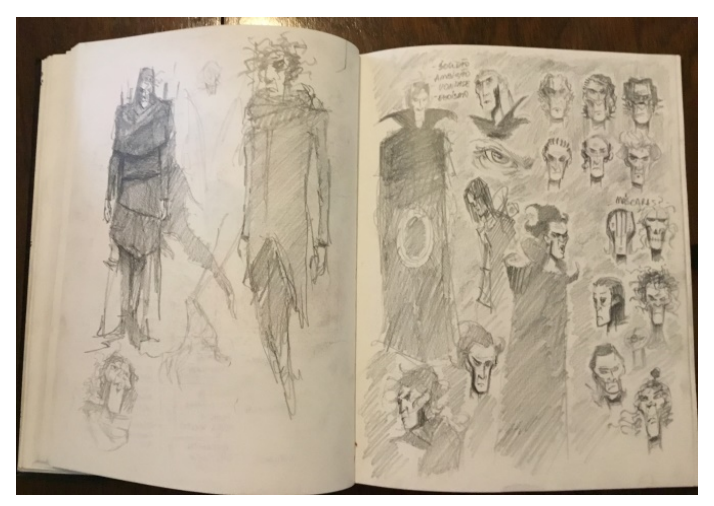

Figure 2: Studies of the main personage, the wizard. Source: Files from author. 


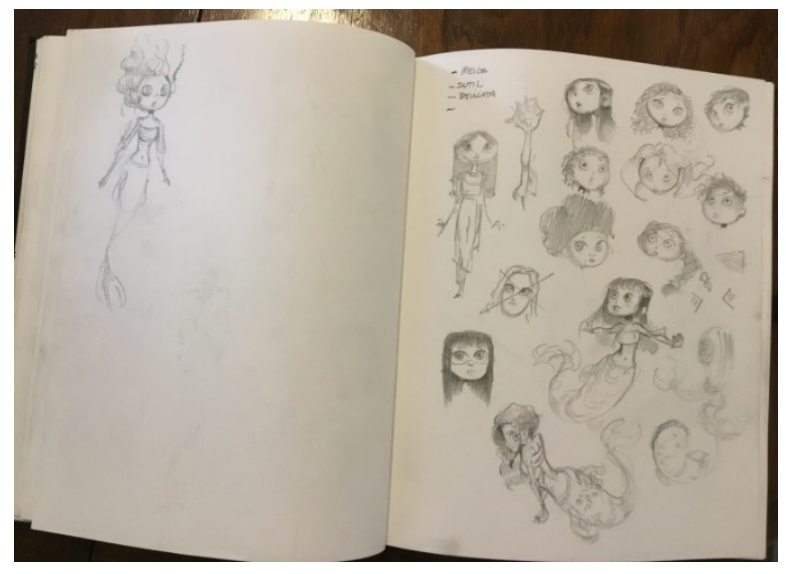

Figure 3: Studies of the daughter of the leader, Gaia. Source: Files from author.

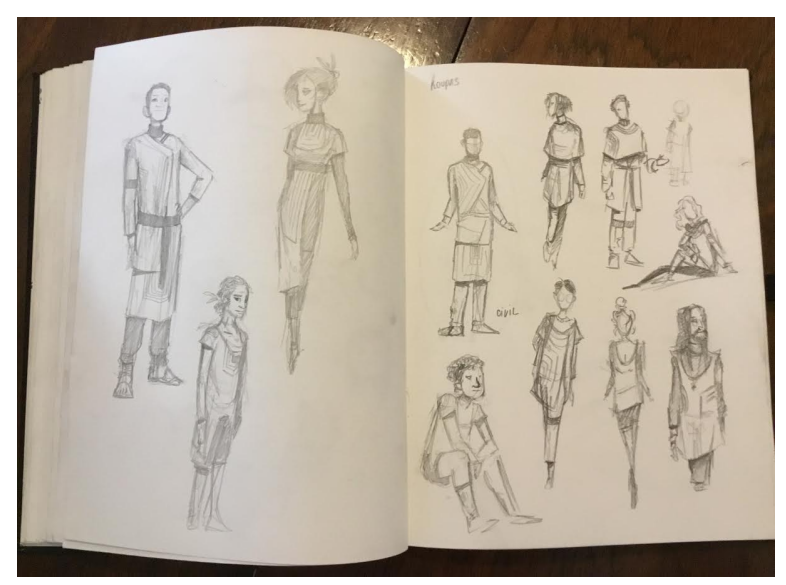

Figure 4 Studies of the friend of Gaia, Buri. Source: Files from author.

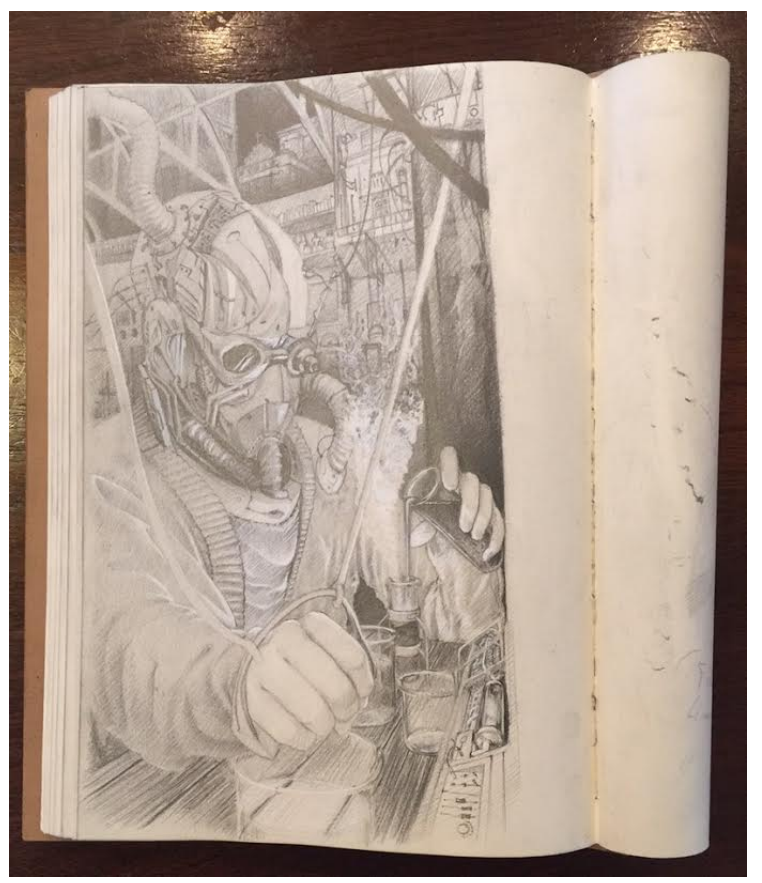

Figure 5: Studies of the old civilisation. Source: Files from author.

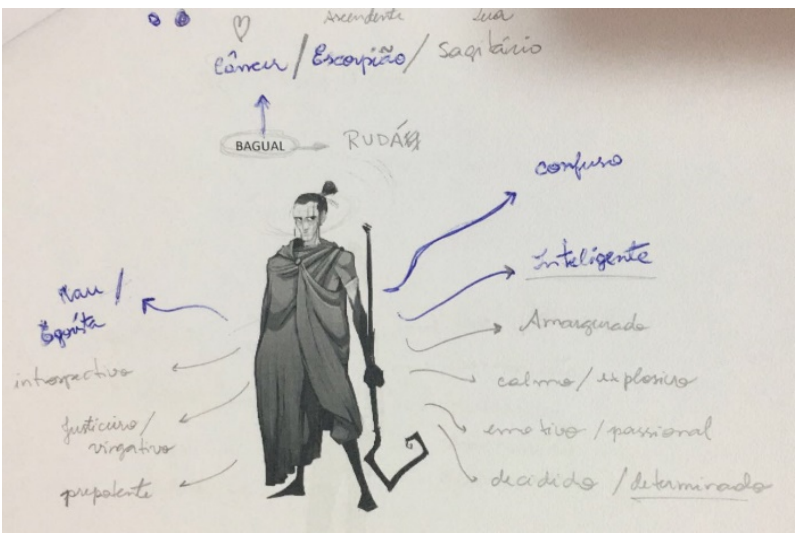

Figure 6: Studies of the personality and identity for main personage, the wizard. Source: Files from author.

Setting/Place: Where does the story take place? The story is placed in a preserved reserve area of the Atlantic Forest, called Grumari, located in Rio de Janeiro. The team visited and documented with videos and photos several points of the reserve before starting the sketches of the scenario.

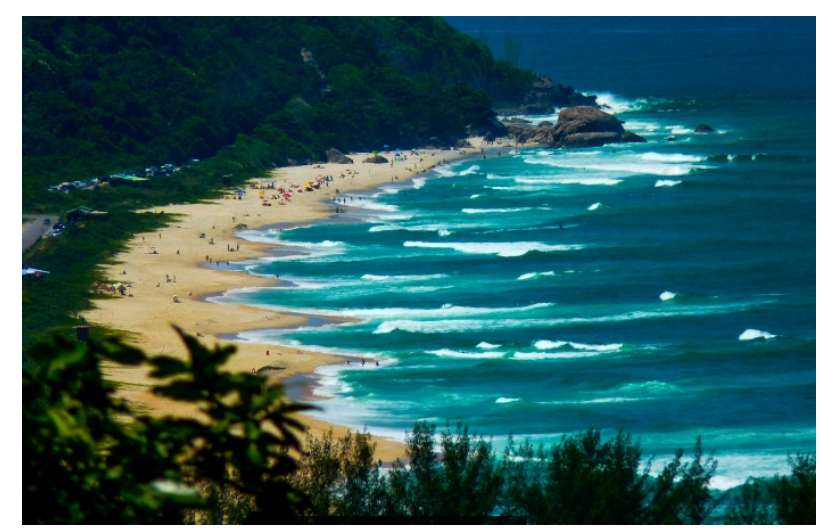

Figure 7: Scenery photography as the basis for illustration. Source: Files from author.

Time: When does the story happen?

The story happens in a future time, after the previous civilisation being destructed by ecological disasters.

Problem: What is it that one or more of the characters want to do or want to happen by the end of the story?

The main dilemma of the story is the relationship between life and death. The protagonist has the power of immortality, but to become immortal it must destroy the reserve in order to transform it in a city that is proper to its plans.

Events: What happens in the story that helps the characters solving the problem?

Understanding the life/death dilemma and the rescue of values by accepting or not the natural cycle of life.

In this sense, the partnership design, visual arts and literature was essential, considering that art, 
according to Cunha \& Fischer (2017), may ensure the space for interactions whose first goal is the symbolic value of the intersubjective interlocution. It is possible, by means of the art, to put up in the world in an authorial way, not submissive, going through different times and meanings and yet, perception and attribution of qualities with sensibility.
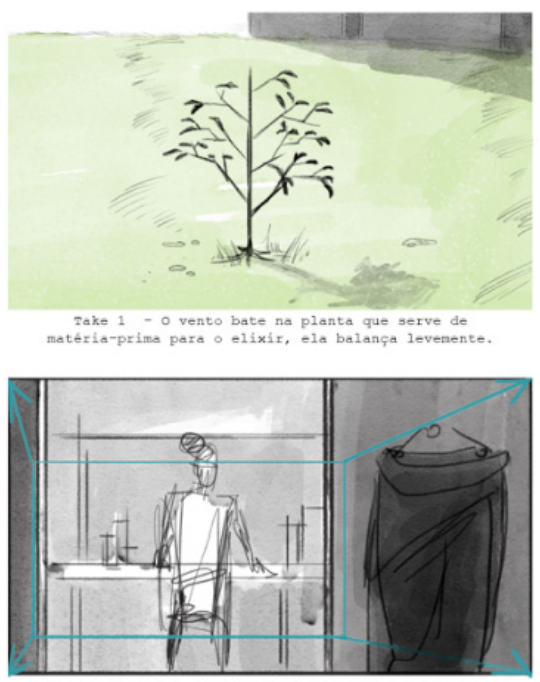

Take 4 - zoom out, Bagual está de contas ainda mexendo
en sou aparato, á direita aparece sou manto negroo.

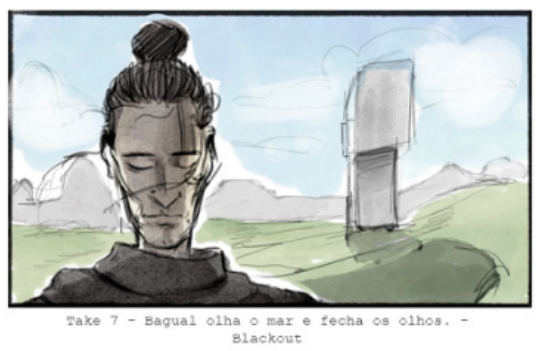

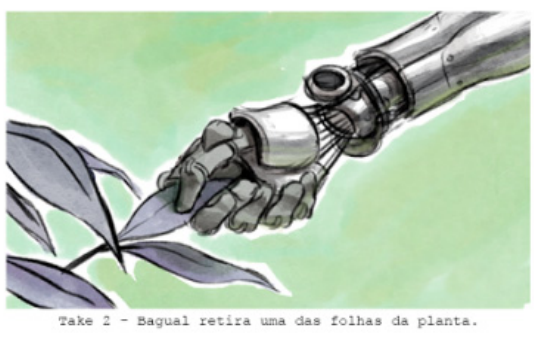
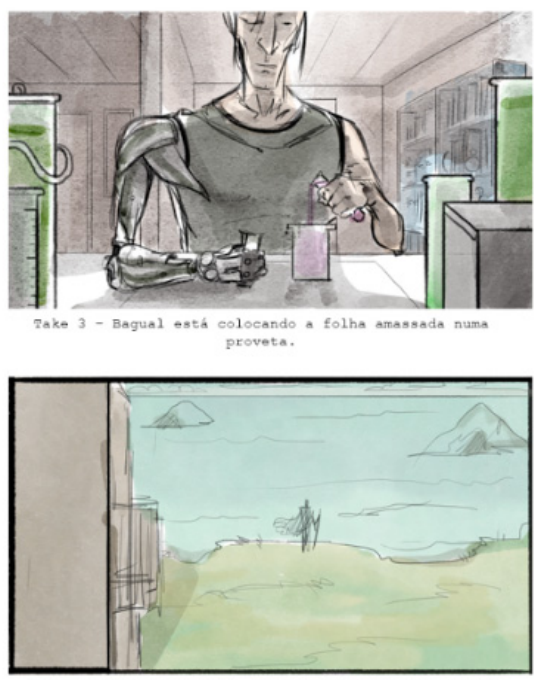

Take 5 - tograt

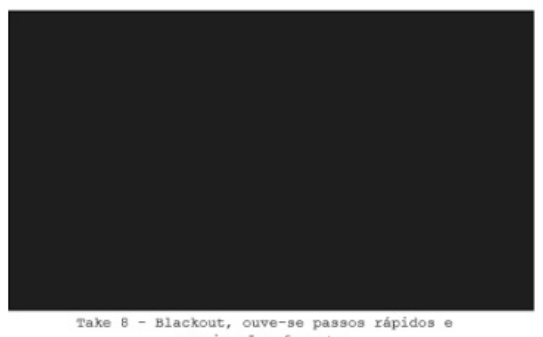

stage of the research is the development of the storyboards aiming to transpose the scenes and characters from the script to dynamic frames of easy visualisation. And to continue following the stages, as in Figure 1.

Figure 6: Storyboard studies for the teaser of the story. Source: Files from author.

\section{CLOSING REMARKS}

By doing this study about the process of developing digital interactive narratives as tools for inclusion of deaf and listening children in society, the intent was to make available a book that children will have the pleasure of reading and interacting with. The team considers that the habit of knowing, listening or reading histories since the early years of life may make people more reflexive and may also collaborate to amplify their critical sense. The digital narrative pretends to be used as a resource for gathering deaf and listening children aiming the acquisition of information, generating knowledge about important aspects of the daily life in society.

The produced narrative started from a free construction. However, by deciding to present it digitally, it involved the knowledge, identity and rationality about how people build the knowledge about the world around them and the interlocution with other people. In this sense, as stated by Galvão (2005), the narratives produced orally, written or by hypermedia, have a huge teaching potential. They may be used both to investigate the knowledge that people expresses as well as to help the process of knowledge building.

The digital literature being developed seeks new horizons of entertainment for deaf and listening children. The digital narrative that will arise will cover many different formats and styles, but it will essentially be a unique and unmistakable entity. It will not be an interactive "this" or "that" - however much of this may be extracted from tradition - but a reinvention of the act of telling stories itself for the new digital media (Murray 2003, p. 236). And that interactive literature may allow an active interaction to all of those participating in this moment.

\section{ACKNOWLEDGMENT}

To CAPES Foundation, Ministry of Education of Brazil, Brasilia - DF, Zip Code 70.040-020. "Bolsista da CAPES - Proc. N. 88881.119789/2016-01". To 
CNPq. To illustrators João Ricardo and Pablo Henrique. To the Researcher's team Eliane Jordy, Ana Correia, Natália Brunnet and Felipe Alram.

\section{REFERENCES}

Carvalho, G. S. (2008) As Histórias Digitais: Narrativas no Século XXI. O Software Movie Maker como Recurso Procedimental para a Construção de Narrações. Dissertação (Mestrado em Educação), Universidade de São Paulo, Brazil.

Cunha, C. M. and Fischer, J. (2017) Ensino da arte e leitura de imagem.

http://www.pucpr.br/eventos/educere/educere2009/ anais/pdf/2540 1250.pdf (accessed 4 March 2017).

Vianna, R. (2012) Rio recebe título de Patrimônio Cultural da Humanidade, G1, 1 July.

http://g1.globo.com/rio-dejaneiro/noticia/2012/07/rio-recebe-o-titulo-depatrimonio-cultural-da-humanidade.html (accessed 2 January 2017).

Galvão, F. T. (2012) Tecnologia Assistiva: favorecendo o desenvolvimento e a aprendizagem em contextos educacionais inclusivos. In: Giroto, C. R. M., Poker, R. B. \& Omote, S. (Org.), As tecnologias nas práticas pedagógicas inclusivas. Marília/SP: Cultura Acadêmica, pp. 65-92.
Jenkins, H. (2006) Cultura da convergência. São Paulo: Aleph.

Murray, J. H. (2003) Hamlet no holodeck: o futuro da narrativa no ciberespaço. Itaú Cultural, Unesp, São Paulo, Brazil.

Oliveira, M. A. (1996) Leitura prazer: interação participativa com a literatura infantil na escola. São Paulo: Paulinas.

Portugal, C. (2013a) Design, educação e tecnologia. Rio de Janeiro: Rio Books.

Portugal, C. (2013b) Design, educação e tecnologia. http://design-educacao-tecnologia.com (accessed 1 May 2017).

Portugal, C. et al. (2015) Design and Narrative for Deaf and Listener Children. In K. Ng, J. P. Bowen \& N. Lambert (eds.), EVA London 2015: Electronic Visualization and the Arts, pp. 100-105. Electronic Workshops in Computing, BCS.

Sweetland. R. (2017) Elements of Story or Fiction character, setting, plot, point of view, style, tone, theme.

http://www.homeofbob.com/literature/genre/fiction/fi cElmnts.html (accessed 2 January 2017).

Vygotsky, L. S. (1998). A Formação Social da Mente: o desenvolvimento dos processos psicológicos superiors. São Paulo: Martins Fontes. 